Marina Dossena

\title{
4 Advice to prospectors (and others). Knowledge dissemination, power and persuasion in Late Modern English emigrants' guides and correspondence
}

This contribution analyzes a collection of nineteenth-century documents meant to circulate information to prospective emigrants to Canada and the US, in order to identify the main linguistic strategies employed to make knowledge credible: if sources could be presented as reliable, their persuasive quality would be enhanced. The materials under investigation comprise both published materials and 'ego documents', such as correspondence and travelogues meant for private circulation. Building on previous studies of familiar letters (Dossena, 2008, and 2012) and on the construction of reliability in business discourse (Dossena, 2010, and 2014), this study will focus on the importance of knowledge dissemination for the establishment and maintenance of (new) networks based on trust in the information provided.

Keywords: Late Modern English, persuasive discourse, ego documents, emigration, social networks.

\subsection{Introduction}

That knowledge is power may seem a truism, and it is for this very reason that such a statement should invite further reflection. In fact, it is not only knowledge per se that grants power to those who detain it, but also the extent to and the ways in which they choose to disseminate it. In this contribution I aim to analyze a collection of nineteenth-century documents meant to circulate information to prospective emigrants, concerning new territories in Canada and the US, in order to identify the main linguistic strategies employed to make knowledge credible by presenting the sources as both exhaustive and reliable, and thus enhancing their persuasive quality.

My analysis will take into consideration both published materials (books and articles in popular journals and magazines) and 'ego documents', such as correspondence and travelogues meant for private circulation. This will enable the investigation of features across a relatively broad sample of authors, from those we can assume to have been fairly educated, such as the authors of journal articles, to minimally-schooled ones, such as those whose usage is often witnessed in emigrants' letters. ${ }^{44}$

44 In this kind of correspondence the writers wished to inform friends and family about their new circumstances, although their level of education did not always afford them much expertise in grammar, spelling, and composition; the consequence is that the texts that can be collected for the preparation of a computerized corpus are far from homogeneous in terms of the linguistic features they employ, which make them both more interesting and more complex to analyze. 
Building on previous studies of familiar letters and journals (Dossena, 2008, 2012, and 2015) and on the construction of reliability in business discourse (Dossena, 2010, and 2014), this study will attempt to shed light on how knowledge dissemination may be an important tool for the establishment and maintenance of (new) networks by inviting trust in the information provided. Conveying persuasiveness may result in an enhancement of the writers' authoritativeness, which in turn may confer greater reliability to their statements. This results in an increase in the power wielded by writers, who select information and thus guide - and actually shape - their readers' acquisition of content. Given the broad range of materials at hand, my methodological approach will be qualitative, in an attempt to highlight discursive strategies; quantitative analyses, which may also be of interest at a later stage, once these strategies have been identified, thus fall outside the scope of this contribution. As for background information, reference may be made to studies by commentators of social and cultural history - among others, Erickson (1972), Gerber (2006), Lewis (2008), Cartosio (2010), Devine (2011), Howe (2012), Calder (2013), and Rose (2014).

\subsubsection{Beyond explorers}

In Late Modern times the number of people who emigrated from Britain to the US, Canada, Australia, and other areas of what would become the British Empire was certainly considerable. ${ }^{45}$ In particular, Canada and the US were of great interest in nineteenth-century Britain: Richards (2012: 144-145) reports that "By 1890 there were more than 1,500,000 British-born people living in Canada, Australia, New Zealand and South Africa. But this was less than half the number in the United States, [...]. The start of the Victorian age witnessed an accelerated rate of emigration [...]".

Not all emigration was voluntary: servicemen and missionaries could be commanded to move to a certain area, with or without their families; convicts were forcibly transported; and victims of the Highland Clearances were left with hardly any choice. Other emigrants, instead, chose their destinations on the basis of what information was available to them and/or what assistance they could get from government agencies and/or emigration societies. In the materials provided by these institutions the aim was to persuade eligible candidates that emigration would be worthwhile, but the opposite could also be true: candidates who might not meet the required standards would have to be discouraged. The same text would thus provide arguments the interpretation of which was left to the readers, who assessed them on the basis of their own circumstances. As mentioned, these were institutional documents. What was on the market could emphasize promotional aspects, not least

45 This contribution focuses on British emigration, though of course the phenomenon was a global one, and guides for immigrants published in the US could and often did address other nationalities. 
owing to the sales the publishers could envisage; as a result, we may expect to find a larger number of publications being issued at times of specific interest, like in the case of the different waves of 'Gold rushes', e.g. in California and Klondike.

Generally speaking, the travelogues of earlier explorers, geographers, and cartographers could no longer cater adequately for an increasingly larger audience of people who could contemplate moving to new territories, for whom a different kind of information was required. As in previous decades, ${ }^{46}$ travelogues could be of interest as narratives of distant countries that would always remain an exotic mirage: indeed, magazines and circulating libraries, but also exhibitions of paintings and - later of photographs, opened windows onto new worlds which elicited curiosity and the desire to know more, thus encouraging more publications. ${ }^{47}$ In addition, descriptions of peoples and landscapes in novels aimed to provide realistic background information, thus contributing to the very 'suspension of disbelief' required of readers of literature. This, however, did not meet the requirements of prospective emigrants, who needed (and indeed expected) the information available to them to be reliable (though sometimes it was not, even in texts that claimed to be all but romanticized). The consequence was that a new market was open for even minimally-schooled audiences, and - in the case of prospective emigrants - publishers were quick to issue booklets aimed at providing information purported to be factual, up-to-date, and of course inexpensive. In addition, prospective emigrants could rely on other sources of information which could circulate in their community, i.e. the letters and diaries sent home by people who had already left the 'Old Country', and even the talks given by people who had visited the places in which they were interested - see for instance Finlayson (1879) and Pullar (1879). These talks could then be printed (either as articles in local newspapers or as independent booklets) for wider circulation.

While the objectivity of letters may be questioned (their aim was often to reassure, as well as to inform - see Dossena, 2008, 2011, and 2012), their persuasive quality as testimonies of personal experience was undoubtedly very high (see Myers, 2003: 269). Nor should we neglect the fact that perhaps some of these writers had already been experiencing the new environment long enough for them to be considered 'experts' who could provide valuable advice, such as detailed comments on what job opportunities were available, what ought to be taken and what could easily be bought upon arrival, etc. Although these letters were obviously addressed to friends

46 Already in Early Modern times the success of the collections published by Richard Hakluyt (Divers Voyages Touching the Discoverie of America, of 1582, and The Principal Navigations, Voiages, Traffiques and Discoveries of the English Nation, of 1598-1600) and Samuel Purchas (Purchas, his Pilgrimage, of 1613; Purchas, his Pilgrim, of 1619; and Hakluytus Posthumus or Purchas his Pilgrimes, of 1625) had greatly contributed to the circulation of information on virtually all corners of the contemporary world.

47 See for instance George F. Ruxton's Life in the Far West, first published in Blackwood's Edinburgh Magazine between June and November 1848. 
and family, they could also be read or at least summarized to acquaintances who expressed an interest in emigration, thus proving a very valuable tool of knowledge dissemination.

The texts under investigation in this chapter comprise materials currently available in the Corpus of Modern Scottish Writing (henceforth CMSW, compiled at the University of Glasgow), the Corpus of Nineteenth-century Scottish Correspondence (henceforth 19CSC, a long-term project currently under way at the University of Bergamo), and digitized texts in library and archive repositories in the UK, Canada, and the US. Given the very high number of potentially available documents, it would be impossible to claim representativeness even if an extremely large corpus were collected. This study is part of a larger, interdisciplinary research initiative in cooperation with historians and literary critics; it will refrain from offering quantitative findings, focusing instead on qualitative, close readings of the texts and of salient features within them (such as titles and subtitles, but also interpolated items like maps and advertisements - see Young Choi, 2015), by means of which a reader's profile was outlined and, as a result, discourse communities were construed and reinforced.

\subsection{Guidance and advice in published sources}

\subsubsection{Keywords in titles}

In books, advice to prospective emigrants was offered in clearly instructional terms, stressing the reliability of the sources and - as a result - the validity of the information at hand. Typically, the author was presented as an eye-witness, either a resident with considerable experience of the areas under discussion, or a visitor whose purpose was both to investigate and to inform - see the following examples:

1. Dudgeon, Thomas, A nine years residence, and a nine months tour on foot, in the States of New York and Pennsylvania, for the use of labourers, farmers, and emigrants. Edinburgh: T. Dudgeon, 1841.

2. Oliver, William, Eight months in Illinois; with information to emigrants. Newcastleupon-Tyne, W.A. Mitchell; E. \& T. Bruce, etc., 1843.

3. [Brown, James Bryce], Views of Canada and the colonists: embracing the experience of a residence; views of the present state, progress and prospects of the colony; with detailed and practical information for intending emigrants, by a four year's resident. Edinburgh: A. \& C. Black, 1844.

Of course the materials issued by emigration societies, specially established to provide help and assistance to emigrants, were perceived to be reliable by definition. In general, however, title pages went to great lengths to promote the books' contents as accurate, recent, exhaustive, and practical, thus presenting the book as a usable and accessible source. In many cases, as we saw above, title pages also outlined 
their ideal readers - not only were these books "for the people", (see [5] below) they were meant to be "the emigrant's friend and guide" (see [4] and [6] below), ${ }^{48}$ often identifying specific targets, such as labourers and mechanics:

4. Anon., The British mechanic's and labourer's hand book, and true guide to the United States: with ample notices respecting various trades and professions. London: C. Knight, 1840.

5. Chambers, William \& Robert, Emigration to Canada, and other British American possessions, Chambers's information for the people, 1842, Nos.17-18. Edinburgh: William and Robert Chambers, 1842.

6. Rolph, Thomas, 1820?-1883. The emigrant's manual: particularly addressed to the industrious classes [...]. London: Cunningham \& Mortimer, [1843?].

An overview of the titles under which emigrants' guides were published may thus shed some useful light on what text types featured within this genre. In addition to manual and guide we find treatise, account, statement, hand book, notes, and scenes: while the first three associate the books with official documents, the last two are closer to ordinary travel narratives - see the examples below:

7. Delano, Alonzo. Life on the plains and among the diggings; being scenes and adventures of an overland journey to California: with particular incidents of the route, mistakes and sufferings of the emigrants, the Indian tribes, the present and future of the great West. New York, Miller, Orton \& co.: 1857.

8. Byers, William N. \& J. H. Kellom, J.H., A hand book to the gold fields of Nebraska and Kansas being a complete guide to the gold regions of the North and South Platte and Cherry Creek: embracing a reliable description of the country, climate, streams, scenery, etc., different routes from the Mississippi River to the mines, the best camping places on reach route, and a reliable map of the area: and valuable information as regards a complete outfit for the journey: containing narratives of trips to and from the gold region in the years 1858-59. Chicago: D.B. Cooke \& Co., 1859.

9. Barnum, E.M. The gold and silver fields of Oregon and Idaho. A statement of the yield of precious metals from the great basin of the Columbia, carefully prepared from the most authentic sources. N.p.: 1867.

10. Borden's Leadville. A treatise on Leadville, Colorado: Reliable information. New Albany, Ind.: Frank A. Cannon, 1879.

48 Although ideas of colonization and settlement do feature on some title pages, readers are typically called 'emigrants', 'pioneer' being a more romanticized label, and more frequent in American sources, as suggested by the OED quotations for those entries relating to the world of geographical exploration (see Dossena, 2016: 51-52). 
Alongside these labels, however, there are others, from which the subjectivity of the presentation emerges more clearly; it is the case, for instance, of diary, journal, autobiography, sketches, and anecdotes - see the following examples:

11. Buffum, E. Gould, Six months in the gold mines: from a journal of three years' residence in Upper and Lower California. 1847-8-9. Philadelphia: Lea and Blanchard, 1850.

12. Shaw, Pringle, Ramblings in California; containing a description of the country, life at the mines, state of society, \&c. Interspersed with characteristic anecdotes, and sketches from life, being the five years' experience of a gold digger. Toronto: J. Bain [1857?].

13. Peters, Charles, The autobiography of Charles Peters, in 1915 the oldest pioneer living in California, who mined in ... the days of ' 49 ... Also historical happenings, interesting incidents and illustrations of the old mining towns in the good luck era, the placer mining days of the '50s. Sacramento, Cal.: The LaGrave co. [1915?].

Among such cases, in which the personalization of the content is emphasized, there are also instances of texts in which correspondence is published: see for instance Campbell (1867), but also - in more recent editions - the following texts:

14. Buck, Franklin A. A Yankee trader in the gold rush; the letters of Franklin A. Buck. Boston, New York: Houghton Mifflin Co., 1930.

15. Delano, Alonzo, Alonzo Delano's California correspondence: being letters hitherto uncollected from the Ottawa (Illinois) Free trader and the New Orleans True delta, 1849-1852. Sacramento, Calif.: Sacramento Book Collectors Club, 1952.

Women were not excluded from this kind of semi-literary account: in fact, their letters were presented as familiar correspondence, i.e. (semi-)personal; this gave them an aura of possible confidentiality which may have made them all the more appealing:

16. The Shirley letters from California mines in 1851-52; being a series of twenty-three letters from Dame Shirley (Mrs. Louise Amelia Knapp Smith Clappe) to her sister in Massachusetts, and now reprinted from the Pioneer magazine of 1854-55; with synopses of the letters, a foreword, and many typographical and other corrections and emendations. San Francisco: Printed by T.C. Russell, 1922.

Emigrants' guides, however, normally stressed their usefulness, also highlighting what additional pieces of information could be gleaned from their pages, especially in relation to the climate, recommended outfits, and potential dangers to be thwarted, like not knowing where fresh water could be found. Basic glossaries of Native languages could also be provided:

17. Palmer, Joel, Journal of travels over the Rocky Mountains, to the mouth of the Columbia River, [...]: containing minute descriptions of the valleys of the 
Willamette, Umpqua, and Clamet: a general description of Oregon Territory [...], tables of about 300 words of the Chinook jargon, and about 200 words of the Nez Percé language [...] a list of necessary outfits for emigrants, and Table of Distances from Camp to Camp on the Route. Cincinnati: J.A. \& U.P. James, 1847.

18. Clayton, William, The Latter-day saints' emigrants' guide: being a table of distances, showing all the springs [...] and all other notable places [...] together with remarks on the nature of the land [...]. St. Louis, MO: Republican steampower press - Chambers \& Knapp, 1848.

Similarly, materials pertaining to assisted emigration schemes, for instance to New South Wales and Van Diemen's Land, i.e. Tasmania, indicated the required supplies for each individual to bring with them on the voyage, and included charts listing the daily food and drink rations provided per person during the trip - see the document dated $20^{\text {th }}$ Oct. 1837, currently held at the National Archives of Scotland (GD268/173/35). ${ }^{49}$

The fact that materials could be audience-specific, such as in the case of certain religious groups (e.g. Mormons), or special-interest parties (e.g. prospectors), indicates that their contents were not always organized in similar ways, though of course basic comments on the climate and geography of the areas under discussion were a typical feature. Being audience-specific, however, did not necessarily mean that less effort was required on the part of the authors to make their texts trustworthy. As a result, in addition to content, it may be useful to gain insights into the persuasive quality of these texts by taking into consideration any supplementary material that was interpolated.

\subsubsection{Maps and more}

Emigrants' guides obviously attempted to be as informative as possible, relying mostly on text, but this was not always feasible when new territories had to be described in geographical terms. Although distances could be listed, fords and springs identified, and itineraries recommended, maps were invaluable in their visual quality, immediately giving an idea of what paths ought to be followed and what cities were nearby. Particularly in guides addressed to prospectors, maps can be found both at the beginning and within the texts themselves - Trout (1886), for instance, includes a map of the Similkameen Country, BC, in the very first few pages of the text, and then presents a map of “the paying portion of Granite Creek” (p. 12) when more detailed information is provided.

49 This can be downloaded from www.educationscotland.gov.uk/higherscottishhistory/migrationandempire/ historical_documents/gd268-173-35.asp (accessed Dec. 2015). 
Informative texts also provided specific data and tables concerning produce, minerals, wages, cattle and the kind of profits that could be expected in the different trades or fields of investment. Among these, Tait (1884) attempted to encourage British investments in the US by outlining the "profits of the cattle business" (Tait 1884: 11-15) and supplemented his text with an appendix in which, in addition to interviews with leading experts in the field, letters were reprinted emphasizing the validity of the investment in American cattle. Notes were also given in which dividends were calculated - see the quotation below:

19. The Texas Land and Cattle Company, In addition to dividing a sum equal to $15 \%$ in cash, show an increase in herd, from natural causes, worth, in the writer's judgment, and at current rates, £57,405, equal to a further $25 \%$. The land, [...] must be credited with an appreciation [...] equivalent to an additional $15 \%$. The dividend earned, and the general growth in value, represent therefore $55 \%$ for the year (Tait 1884: 70, original emphasis)

Also Barnum (1867), whose text is addressed "to the financial and commercial men of the country" (title page), presented statements concerning the gold deposited in the mint and its branches over three fiscal years (1864, 1865, and 1866) from different mining states and territories, so that the yield of the different areas could be compared, and the fields of Oregon and Idaho could be highlighted. As for the sources of these data, Barnum stressed their reliability by referring to official documents, such as "the returns made to the Commissioner at Washington City" (p. 6). Indeed, Barnum attributed "a greenback valuation" of the Bullion product of the Owyhee district from January to October 1866 to "John A. Post, Esq., the internal revenue collector" (p. 12). When newspapers are cited (the Dalles Mountaineer and Walla Walla Statesman), they are qualified as being "published at thriving towns on the Columbia" (p. 6). In all cases the quality of the sources is made prominent.

This quick, clear, and accessible way to summarize data enabled readers to get an overview of what might interest them most by focusing directly on the items that appeared to be most relevant to them. Tables also enabled efficient data comparisons, thus saving the readers' time and making the book more cost-effective. Although they could be restricted to materials addressed to a more informed audience, their significance as a valuable tool of knowledge dissemination ought not to be neglected.

Once information was acquired, readers could feel they belonged to a new discourse community, one in which participants shared competence and similar needs. As a result, these books are not devoid of ads promoting objects and services. The publisher of Borden (1879), for instance, supplemented its 39 pages with as many as 11 ads, most of which occupy half a page: they concern transport ("the shortest and best route for all points west" [unnumbered page]), a bank and an insurance company, a newspaper, a furniture dealer, a stove foundry, and a company selling 
both liniments and inks of different types for different business purposes. Also Trout (1886) interspersed and supplemented its 64 pages with ads for real estate brokers and financial and insurance agents, iron works, miners' outfits, a painter, a glazier and paper-hanger, grocers, blacksmiths and shoe stores specifically addressing miners, a travel agent, a watchmaker and jeweller, a doctor, a barber, a brewer, a dentist, an engraver and stencil cutter, a photographer, an importer of musical instruments, a gun and rifle-maker, a book-binder, a baker, a crockery dealer, a builder, a butcher, an architect, a cigar store, a barrister, a tailor, accountants and stenographers, a saloon, and even a Japanese store. Beyond the content of the book itself, which was addressed to "emigrants, tourists, sportsmen and gold seekers" (title page), the idea of the community growing in the area, and of which the readers could become a part, was also conveyed by these references to aspects of daily life ranging from the bare necessities of food and equipment, to more sophisticated traits, such as those suggested by the presence (in the neighbourhood) of a jeweller and an importer of musical instruments. Perhaps it would have been too expensive for the publisher to include images. However, these ads, with their varying fonts and attention-seeking descriptions of what was on offer, also helped readers imagine a new environment to which they could move and where they could live in comfort and prosperity.

\subsection{Guidance and advice in familiar correspondence}

In interaction, whether spoken or written, the presupposition of the truthfulness of the predication is vital - it is not by accident that one of Grice's fundamental Maxims in the definition of the Cooperative Principle concerns Quality, i.e., the fact the speaker is expected to tell the truth, or at least what they believe to be the truth (see Grice, 1975). Correspondence is therefore expected to embody a reliable representation of the participants' reality, though of course, as we mentioned before, the wish to reassure distant readers may not be excluded. This is in fact very clear in the typical health-related formula with which writers greet their readers immediately after the opening salutation. Before any other business is discussed, writers inform readers that everybody is in good health, or has recovered, if they had been ill or injured, and express the same wish for the recipients. As for actual content, letters typically concern descriptions of the land and climate, accounts of everyday life in the community, work and wages, and requests for objects that might be useful or pleasurable, such as newspapers from home (see Dossena, 2008, and 2011).

When letters are addressed to prospective emigrants, however, they can be quite detailed in relation to what might be required to equip the newcomers appropriately and suitably. The examples below are eloquent in their attempt to provide guidance 
in relation to what is to be packed, how it ought to be packed, so as to save on duty, and why it ought to be packed, especially because some goods will prove profitable: ${ }^{50}$

20. Dear Brother [...] Be sure to Bring your self shoes enogh to last you 3 or 4 years [...] you may lay out 20 pounds sterling in shoemakers threed this article will dubel its valey Easey but it must be of the best kind fetch one pice of the best kind of blue cloth + I want my Brothers + you to hav a folce Bottom put in your Chists about 6 Inches Dip and filed with the best kind of Calf Skins for boot legs this you will likely dubel on and by doing as I told you you will sav the dutey which is verey high [...] Be sure to fetch the fowling articols which you will find greatly to your advantage that is 4 packs of the best kinds pototies 2 pecks of the best wheat 2 Do of oats [...] bring one of the best kind of single Bareld shot guns with you as Geam is hear verey plenty Try to bring 3 of the Best kind of pear trees 3 Do of Appels 3 of plumbs +3 of gusbereys +10 gallon cas of the best kind of West Cuntry Herrings [...] 10 or 12 Botels of the best Scotch Whisky 2 pecks of Barly [...] NB Bring 2 of the best kind of 10 gallon Bras Bottels

(brother to brother, Caldwell Country, 07.11.1818, 19CSC)

21. Dear Brother [...] I mentioned in my former letters the things I want out in the Spring Say 2 pare Boots $2 \mathrm{D}^{\circ}$ Showes two Suts of Light Clothes for Sumer, one of the men of the Tritton called and said to your Sis+ster that John Son James would wish to come out and learn the Carpenter Bus+snes+s I think if he inclines to lern that tread I think he kanot dow Better as he will sun be a help to Mr Neilson as I intend to leave the Bus+snes+s to him in a year or two

(brother to brother, Quebec, 14.12.1831, 19CSC)

22. Dear Brother [...] i think that if you was hear now you would have a good Chance in the ordanary Cours of providence to dowell if you and your famley head their health [...] i would be glad to see you Come hear if you thought you were able and if you thou ${ }^{\text {ght }}$ you wer sure you had gods Call for to Com Dear Bro ${ }^{\text {ther }}$ it ould be a glad sight to me for to se any of my friends Come to us but purticularly you but $\mathrm{i}$ would never advis ${ }^{\mathrm{e}}$ any of you to come except you see your way [torn]

(brother to brother, London, ON, [illegible].04.1842, 19CSC)

50 I gratefully acknowledge permission to quote from MSS held in the National Library of Scotland and the Bank of Scotland Archives in Edinburgh, Glasgow University Archives, and the Thomas Fisher Rare Book Library in Toronto; such permission does not extend to third parties, so the quotations presented in this paper should not be used elsewhere. I am also indebted to Richard Dury for his help in the design and compilation of 19CSC. In all quotations word, line and page breaks are omitted. Spelling is retained as in the original, including linked-up words and long $\langle\mathrm{s}\rangle$, transcribed as $\langle\mathrm{s}+\rangle$. The names of the people mentioned in the letters are replaced by [...] for reasons of privacy; for the same reason, names are replaced with qualifications where sources and dates are provided. At the moment 19CSC comprises a total of nearly 400 letters, for a total of ca. 100,000 orthographic units. 


\subsection{Description and evaluation}

Although meant for different audiences, both published and unpublished materials provide information by means of descriptions, alongside with evaluations, so as to guide the readers' interpretation of what may be - or perhaps ought to be - considered in a more or less positive light. In manuscript sources, such as letters, the stronger ties existing in the participants' network may allow for more direct comments than in texts addressed to the general public, in which the authors' convictions and assessments may need to be expressed in less explicit terms. However, this is also a function of the virtual proximity that writers wish to convey to their audiences: the closer they want to bring them to their text, the more transparent and unhedged the message can be. In what follows, examples are given concerning attitudes to the abolitionist movement. The first two are derived from familiar correspondence, and therefore express their authors' stance in relation to the matter or evaluations of similarities and differences with situations in England and Ireland. The third one, on the other hand, is in a published source, and therefore argues against slavery on the grounds of reasons that go beyond ideology (i.e. a subjective view) and instead concern salaries and the organization of labour in general, thus giving an idea of greater objectivity as these are presented as issues on which everyone can agree on account of their being common-sense observations:

23. there is nothing of note stirring in this country at present with the exception of some fanatical _ abolitionists sent from england and which I hope to see tarred and feathered for their pains let stay at home and look inside of some of there large factorys and they will see slavery enough. here Niger works 7 hours a day better fed than the Midling Classes in General in Brittain

(son to parents, Philadelphia, 19.08.1835, 19CSC)

24. It is a little singular that Gladstone should not have noticed the points of similarity between the Irish question and those of the Southern Confederacy_There is however one very notable point of difference between the cases. The Irish are, or at least a part of them, in a state of revolt against a Government which [...], has a legal and legitimate sovereignty over them, [...]. On the other hand the Southern Confederacy had a legal right to withdraw from the Federal compact in consequence of a violation of the agreement under which the Constitution was signed by the parties.

(brother to brother, Camden, SC, 21.07.1889, 19CSC)

25. The chief slave states are Virginia, the Carolinas, Georgia, Alabama, Mississippi, Louisiana, Tennessee, Kentucky, Missouri, and Florida. [...]. This is a matter of importance to the intending emigrant, since the slave states are unsuitable for his purposes. The mechanic and farm-labourer will not seek a country where honest industry is associated with bondage and all its degradations. But what is more material, there is no room for him; where services may be enforced there is always a superabundance of it going.

(Anon. 1854: 80) 
What all these comments have in common is the aim to reinforce solidarity by sharing common ground. The subjectivity of evaluations needs to be negotiated very carefully, so as to make such evaluations acceptable to the recipients, who may or may not have a similar point of view, either because of unfamiliarity with the topics at hand or because of relatively diverging ethical and political convictions. As a result, when these phenomena are taken into consideration from a historical sociolinguistic perspective, it may be useful to rely on Appraisal theory (Martin and White, 2005, and White, 2007), which provides a comprehensive and accurate framework for the study of texts in which the interaction of semantics and pragmatics is particularly important. In the study of authorial voices and textual personae such as we find in documents meant to provide guidance and advice by supplying information and description, it is clear that a very important role is played (in more or less explicit ways) by Attitude (i.e., emotional or affectual responses), Engagement (i.e., acknowledging, ignoring or rejecting different view-points, for instance employing evidentiality, concessive forms and presumptions), and Graduation (i.e., strengthening or downtoning statements or their semantic focus). In particular, expressions of Attitude comprise three sub-systems: Affect (relating to emotion), Judgement (relating to the implicit or explicit evaluation of behaviour with respect to social norms), and Appreciation (relating to the evaluation of objects). All these traits occur in the texts under discussion and - as we saw above - Attitude may be more or less personalized, giving greater or lesser visibility to the writer, and inviting greater or lesser involvement on the part of the reader. The credibility of the contents is emphasized by means of strategies in which objectivity and subjectivity coexist, and this subtle balance between contrasting approaches is maintained to ensure the viability of the text itself.

\subsection{Concluding remarks}

In this overview of both published and unpublished materials providing guidance and advice to prospective emigrants, gold seekers, miners, or anyway new settlers in previously unfamiliar territories, we have seen the importance of going beyond the mere text and any traits that may be easily quantified, in order to take a more encompassing approach. The aim of providing information in clear and acceptable ways relies on a need to reduce psychological distance, so that views may be shared on the presupposition that participants stand on common ground. Knowledge is shared by stressing the writers' experience and expertise, but also stressing the profitability of the details and suggestions offered in the texts for the readers who may care to take them into consideration. The virtual dialogue between participants thus contributes to the establishment of new networks, and readers find themselves invited to join a new discourse community, in which competence is circulated in effective ways. While in familiar correspondence the reliability of writers is almost taken for granted, in published materials this process of content-validation is enhanced by the presence of features like maps, tables, statistics, and third-party, eye-witness 
accounts. Even advertisements are meant to cater for the envisaged readers' needs as if they already belonged to the new reality described in the text. Far from being mere accounts of distant worlds, the texts investigated here attempt to provide readers with a vision of what their future life may be like. The undoubted ideological overtones that occasionally occur coexist with representations that attempt to be reliable in their assessments. This intriguing blend of objectivity and subjectivity makes these documents as valuable for socio-historical linguists today as they were for their original readers in Late Modern times.

\section{References}

\section{Primary sources}

19CSC, Dossena, Marina \& Dury, Richard (compilers). A Corpus of Nineteenth-Century Scottish Correspondence, in preparation.

Anon. 1854. The emigrant's manual. America. London: Chambers.

Barnum, E.M. 1867. The gold and silver fields of Oregon and Idaho. A statement of the yield of precious metals from the great basin of the Columbia, carefully prepared from the most authentic sources. N.p.

Borden, William W. 1879. Borden's Leadville. A treatise on Leadville, Colorado: Reliable information. New Albany, Ind.: Frank A. Cannon.

Campbell, John F. 1867. My circular notes. Extracts from journals, letters sent home, geological and other notes, written while travelling westwards round the world, from July 6, 1874, to July 6, 1875. London: Macmillan \& Co.

CMSW, A corpus of modern Scottish writing, www.scottishcorpus.ac.uk/cmsw/ (accessed August 2014).

Finlayson, Archibald W. 1879. A trip to America: A lecture delivered by AWF, Johnstone, near Glasgow, in the Public Hall of the Johnstone Working Men's Institute, 18th March, 1879. Glasgow: Printed by D. Wilson.

Oxford English dictionary (OED-3), www.oed.com (accessed August 2014).

Pullar, Robert 1879. Notes of an American trip: Being the substance of an address delivered in Free St. Leonard's Church Hall, Perth, by Robert Pullar, Esq., on the evening of Saturday, November 22, 1879. Reprinted from the Perthshire Advertiser for private circulation.

Tait, J. S. 1884. The cattle-fields of the Far West: Their present and future. Edinburgh: William Blackwood \& Sons.

Trout, P. L. 1886. Prospectors' manual: Being a full and complete history and description of the newly discovered gold mines on Granite Creek, the canyon of the Tulameen River, and other new mineral discoveries in the Similkameen Country. N.p.

\section{Secondary sources}

Calder, Jenni 2013. Lost in the backwoods. Scots and the North American wilderness. Edinburgh: Edinburgh University Press.

Cartosio, Bruno 2010. Ways of the West: History and literature/fiction and truth. In Angela Locatelli (ed.), The knowledge of literature IX, 39-56. Bergamo: Bergamo University Press.

Devine, Tom M. 2011. To the ends of the earth, Scotland's global diaspora, 1750-2010. London: Penguin. 
Dossena, Marina 2008. 'Many strange and peculiar affairs': Description, narration and evaluation in Scottish emigrants' letters of the $19^{\text {th }}$ Century. Scottish Language 27. 1-18.

Dossena, Marina 2010. Building trust through (self-)appraisal in nineteenth-century business correspondence."In Paivi Pahta, Minna Nevala, Arja Nurmi \& Minna Palander-Collin (eds.), Social roles and language practices in Late Modern English (Pragmatics \& Beyond New Series 195). 191-209. Amsterdam \& Philadelphia: John Benjamins.

Dossena, Marina 2011. Colliers, farmers, strikers. The discussion of work-related themes in Late Modern Scottish letters and diaries. Revista de Lenguas para Fines Específicos (LFE) 17. 319-340.

Dossena, Marina 2012, "I write you these few lines": Metacommunication and pragmatics in $19^{\text {th }}$-century Scottish emigrants' letters. In Ulrich Busse \& Axel Hübler (eds.), Investigations into the meta-communicative lexicon of English. A contribution to historical pragmatics (Pragmatics \& Beyond New Series 220), 45-63. Amsterdam \& Philadelphia. John Benjamins.

Dossena, Marina 2014. 'There is reason to believe however...'. The construction of trust as reliability in Late Modern English correspondence and non-literary prose. In Katja Pelsmaekers, Geert Jacobs \& Craig Rollo (eds.), Trust and discourse, organizational perspectives (Discourse Approaches to Politics, Society and Culture 56), 181-199. Amsterdam \& Philadelphia: John Benjamins.

Dossena, Marina 2015. 'Across the ocean ferry': Point of view, description and evaluation in nineteenth-century narrations of ocean crossings. In Marina Dossena (ed.), Transatlantic perspectives on Late Modern English (Advances in Historical Sociolinguistics 4), 117-134. Amsterdam \& Philadelphia: John Benjamins.

Dossena, Marina. 2016. America through the eyes of nineteenth-century Scots: The case of ego documents and popular culture. In Marina Dossena \& Stefano Rosso (eds.), Knowledge dissemination in the long nineteenth century. European and transatlantic perspectives. 45-64. Newcastle u.T.: Cambridge Scholars.

Erickson, Charlotte. 1972. Invisible immigrants. The adaptation of English and Scottish immigrants in nineteenth-century America. Ithaca: Cornell University Press.

Gerber, David A. 2006. Authors of their lives: The personal correspondence of British immigrants to North America in the nineteenth century. New York: New York University Press.

Grice, Paul H. 1975 [1989]. Logic and conversation. In Peter Cole \& Jerry L. Morgan (eds.), Syntax and semantics, 3: Speech acts. New York: Academic Press. Reprinted in Paul H. Grice (ed.), Studies in the way of words, 22-40. Cambridge, MA: Harvard University Press.

Howe, Daniel W. 2012. The Victorian period of American history. In Martin Hewitt (ed.), The Victorian world, 708-724. Abingdon: Routledge.

Lewis, Robert M. 2008. Wild American savages and the civilized English: Catlin's Indian Gallery and the shows of London." European Journal of American Studies 3(1).1-18, http://ejas.revues.org/2263, accessed January 2016.

Martin, James R. \& Peter R.R. White. 2005. The language of evaluation, Appraisal in English. London: Palgrave Macmillan.

Myers, Greg 2003. Discourse studies of scientific popularization: Questioning the boundaries. Discourse Studies 5(2). 265-279.

Richards, Eric 2012. Human traffic. In Martin Hewitt (ed.), The Victorian world, 141-159. Abingdon: Routledge.

Rose, Kenneth D. 2014. Unspeakable awfulness. America through the eyes of European travelers, 1865-1900. New York: Routledge.

White, Peter R. R. 2007. Appraisal. In Jan-Ola Östman \& Jef Verschueren (eds,), Handbook of pragmatics online. Amsterdam \& Philadelphia: John Benjamins, s.v., www.benjamins.com/online/hop (accessed August 2013).

Young Choi, Tina. 2015. The railway guide's experiments in cartography: Narrative, information, advertising. Victorian Studies 57(2). 251-283. 